\title{
Article
}

\section{PTSD and Female Sexuality in the Aftermath of Childhood and Adolescent Sexual Abuse in Una's Becoming Unbecoming}

\author{
Michael, Olga
}

Available at http://clok.uclan.ac.uk/31128/

Michael, Olga ORCID: 0000-0003-0523-9929 (2020) PTSD and Female Sexuality in the Aftermath of Childhood and Adolescent Sexual Abuse in Una's Becoming Unbecoming. Journal of Graphic Novels and Comics, 11 (4). pp. 394-411. ISSN 2150-4857

It is advisable to refer to the publisher's version if you intend to cite from the work. http://dx.doi.org/10.1080/21504857.2020.1773886

For more information about UCLan's research in this area go to http://www.uclan.ac.uk/researchgroups/ and search for <name of research Group>.

For information about Research generally at UCLan please go to http://www.uclan.ac.uk/research/

All outputs in CLoK are protected by Intellectual Property Rights law, including Copyright law. Copyright, IPR and Moral Rights for the works on this site are retained by the individual authors and/or other copyright owners. Terms and conditions for use of this material are defined in the policies page.

\section{CLoK}

Central Lancashire online Knowledge www.clok.uclan.ac.uk

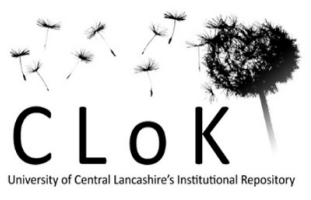


PTSD and Female Sexuality in the Aftermath of Childhood and Adolescent Sexual Abuse in Una's

\title{
Becoming Unbecoming
}

Olga Michael

\begin{abstract}
In this essay, I examine the representation of female sexuality in the aftermath of childhood and adolescent sexual abuse and in the course of post-traumatic stress disorder (PTSD) in Una's Becoming Unbecoming (2015). Drawing from work on mental illness, social justice, and graphic medicine, I investigate the narrativization of the autobiographical subject's suffering through the comics medium. My aim is to show how Becoming Unbecoming counters the silences and stereotypes existing around the sexuality of abused and mentally ill women and girls. In her attempt to represent the symptoms of PTSD -- itself the outcome of sexual violence -- and to remove stigma from female rape survivors, Una makes use of braiding and metaphors in her narrative. These allow for a complex demonstration of PTSD symptoms and of the autobiographical subject's desire for (sexual) intimacy as she grows up. In this way, Becoming Unbecoming breaks into the silence and challenges the stereotypes that render the sexuality of (mentally ill) women and girls invisible at best and perverse at worst.
\end{abstract}

\section{Keywords}

Becoming Unbecoming; post-traumatic stress disorder (PTSD); mental illness; female sexuality; sexual violence; comics 
Introduction

In this essay, I examine the representation of female sexuality in the aftermath of childhood and adolescent sexual abuse and in the course of post-traumatic stress disorder (PTSD) in Una's graphic memoir Becoming Unbecoming (2015). Rather than recreating detailed rape scenes in her book, Una focuses instead on the impact of sexual violence on her journey from girlhood to womanhood and on the exploration of her developing sexuality for which she is constantly shamed and marginalized within educational and family institutions. In addition to presenting the impact of sexual violence on the autobiographical subject's mental health, Becoming Unbecoming shows how the rape culture of victim-blaming and slut-shaming reproduced through the media, school, and the arts prolongs the autobiographical subject's PTSD. In so doing, this culture lifts responsibility away from the victim to place it on perpetrators as well as within broader cultural and social contexts that impose or enable the silencing of sexually abused women and girls and hinder their recovery from trauma.

Drawing from critical work on mental illness, social justice, and graphic medicine, I investigate the narrativization of the autobiographical subject's suffering through the comics medium. My aim is to show how Becoming Unbecoming counters the silences and stereotypes existing around the sexuality of abused and mentally ill women and girls. In her attempt to represent the symptoms of PTSD -- itself the outcome of sexual violence -- and to remove stigma from female rape survivors, Una makes use of braiding and metaphors in her narrative. ${ }^{1}$ The mediation of these elements throughout the narrative allows for a complex demonstration of PTSD symptoms and of the autobiographical subject's desire for (sexual) intimacy as she

\footnotetext{
${ }^{1}$ Braiding refers to the repetition of particular visual motifs within a graphic narrative, which charges the text as a whole with additional meaning. See Groensteen 146.
} 
grows up. As such, it breaks into the silence and stereotypes that render the sexuality of (mentally ill) women and girls invisible at best and perverse at worst.

Comics, Sexual Violence, Female Sexuality, and Mental Illness

Since the 1970s, when women's autobiographical comics first emerged in the American underground comix scene with Aline Kominsky-Crumb's work, depictions of female sexual experimentation and gendered sexual violence against girls and women have become common in the genre. ${ }^{2}$ In addition to Kominsky-Crumb, other female cartoonists have addressed female sexuality and the sexual violence they suffered during childhood, adolescence, or adulthood, visually displaying scenes of rape or implicitly alluding to them and thus working towards countering the silencing of female abuse survivors. ${ }^{3}$ Currently, we are witnessing the proliferation of another "taboo" issue in graphic memoirs, which has, for more than two centuries, been discursively formed primarily through medical and scientific discourses: that

${ }^{2}$ Love that Bunch (1990), for example, an edited collection of Kominsky-Crumb's comics from the 1970s and 1980s, opens with "The Young Bunch: An Unromantic Nonadventure Story" (1976), which describes a case of forced sexual intercourse between adolescent Bunch, Kominsky-Crumb's autobiographical alter ego, and Al, a man she meets at a party. For a discussion of the representation of sexual experimentation and sexual violence in women's underground comics, see Chute 1-28; Sabin 121-133.

${ }^{3}$ Some examples include Phoebe Gloeckner's A Child's Life and Other Stories (2000) and The Diary of a Teenage Girl: An Account in Words and Pictures (2002), Lynda Barry's One! Hundred! Demons! (2002), Julie Doucet's Dirty Plotte (2003), and Debby Drechsler's Daddy's Girl (2008). 
of mental illness. ${ }^{4}$ Graphic memoirs about obsessive compulsive disorder (OCD), bipolar disorder, and depression, to name just a few examples, offer accounts of how such illnesses are experienced by patients, both personally and relationally, as well as by their families, friends, and doctors. ${ }^{5}$

According to Michael J. Green and Kimberly R. Myers, "graphic pathographies," otherwise known as graphic illness narratives, can be used in medical education and patient care to "provide doctors with new insights into the personal experience of illness" (574). Such texts perform complex visual/verbal interplays to "foreground liminal experiences of the vulnerable body which is un/misrepresented by mainstream narratives" and throw "light on the moral and ethical practices of the medical establishment" (Kasthuri and Venkatesan 12). In his examination of prose pathographies and autofiction, Graham J. Matthews writes that rather than being "reduced to a body subjected to biomedical treatment" by telling one's story of illness, a patient can have her or his voice restored (126). The possibility to gain agency over one's experience of illness is particularly important for mental illness narratives since through the course of history the mentally ill individual, and more so, the mentally ill woman and girl, have been muted and reduced to "docile bodies" undergoing constant objectification,

${ }^{4}$ For an extended discussion of the medical discursive formation of mental illness, see Foucault, Madness and Civilization ix-xii; The Will to Knowledge 55-56.

${ }^{5}$ Alison Bechdel's critically acclaimed Fun Home: A Family Tragicomic (2006), for example, relates the development of Alison's OCD during her childhood. Darryl Cunningham's Psychiatric Tales (2010) describes a medical practitioner's personal and relational experiences of depression, schizophrenia, and other mental illnesses. Lastly, Ellen Forney's Marbles: Mania, Depression, Michelangelo and Me (2012) relates the cartoonist's diagnosis of bipolar disorder and her struggle with mania, depression, and medication. 
surveillance, and manipulation (Foucault, Discipline and Punish 144). ${ }^{6}$ Becoming Unbecoming, which depicts unreported cases of gendered sexual violence and the autobiographical subject's struggle with PTSD, undoes the docility of the sexually abused and mentally ill girl and woman by presenting the female survivor's perspective on her abuse and her illness.

Ian Williams proposes that "comics of illness and suffering constitute a significant source of alternative knowledge about the body, health and disease" because of their complex and nuanced negotiations of illness and the invisible feelings that accompany it ("Graphic Medicine: The Portrayal" 81). Such texts, he explains elsewhere, can "provide companionship through shared experience in a more immediate manner than might be gained from joining a self help group or reading patient information leaflets" ("Graphic Medicine: Comics"). In addition to illnesses that are manifested on the body, comics can represent those that are concealed or invisible (like mental illnesses) and, in both instances, the graphic depiction of their embodied experiences can expand readers' awareness of a person's suffering (Williams, "Comics and the Iconography" 115-142). Graphic narratives of sexual violence also allow readers to access survivors' experiences in unique ways because they allow, inter alia, the display of repeated images and visual metaphors that visually capture the complexities and pain of sexual suffering.

For instance, Phoebe Gloeckner's A Child's Life and Other Stories (2000) opens with a "Foreword" accompanied by a self-portrait of Phoebe with Pemphigus Vulgaris, an autoimmune illness that makes the skin decompose (6). While Gloeckner clarifies that she

\footnotetext{
${ }^{6}$ Foucault writes that "the notion of 'docility' [...] joins the analysable body to the manipulable body. A body is docile that may be subjected, used, transformed [...]," shaped, and trained to obey the powers it is subjected to (Discipline and Punish 144).
} 
never suffered from this illness, her nude self-portrait presents a grotesque spectacle that metaphorically captures the autobiographical subject's psychic injuries by visually translating them into blisters and open wounds on her naked skin (see Michael, "Lolita" 51). ${ }^{7}$ Becoming Unbecoming includes nuanced metaphors in its depiction of Una's experiences of sexual violence and PTSD, and of her developing sexuality in the aftermath of abuse. As such, it joins other graphic narratives of illness and sexual trauma as a valuable resource not only for those interested in life writing and comics studies, but also for practitioners working with sexual abuse survivors and PTSD patients, as well as for survivors and patients themselves.

While scholarly attention has primarily focused on the comics representation of sexuality and mental illness in isolation from each other, research that brings them together remains, to a large extent, a desideratum, pointing towards a prevailing silence around their representation as co-existent. In Sexuality and Serious Mental Illness (1999), Peter F. Buckley et al. note the "stereotypical impression [...] that persons with serious mental illness are either asexual or have bizarre sexual experiences" (8). They write that many studies undertaken during the 1970s in the United States concluded that "persons with serious mental illness were incapable of meaningful sexual relationships" (9). In 2010, Joanna Davison and Annette Huntington pointed out that even though "sexuality is a complex and fundamental aspect of a person's health and mental wellbeing [...], mental health professionals generally seem reluctant to discuss sexuality related issues and few research studies have specifically explored the sexuality of women with enduring mental illness" (240). In so doing, they highlight the

\footnotetext{
${ }^{7}$ Comics scholars like Elisabeth El Refaie (149-174), Renata Lucena Dalmaso (75-92), and Nancy Pedri with Helene Staveley (230-256) have also demonstrated how the use of metaphors in comics enriches the representation of mental illness.
} 
double invisibility imposed on the sexuality of mentally ill women because of their illness and their gender.

Having interviewed eight women, Davison and Huntington observe that "powerful interlocking systems controlled and influenced how the women expressed their sexuality, often marginalizing them, positioning them as 'Other', and rendering their sexuality hidden and unseen" (240). In closing their study, they underscore "the need for mental health professionals to recognize sexuality as an important aspect of a person's care and recovery, and to create a culture that is supportive of a person's sexuality and sexual expression" (240). Writing about her own experiences of mental illness and the erasure of her sexuality, Patricia E. Deegan explains that mentally ill individuals "do not cease to be human beings by virtue of [their] diagnosis [and that] like all people, [they] want to feel loved, valued and desired by others" (21). She also points out that "the greatest and most healing service that can be offered to people with psychiatric disabilities is to treat them with respect and honour them as human beings. This means honouring [them] in [their] full humanity, including [their] sexuality and [their] desire to love and be loved" (21). In Becoming Unbecoming, the victim of childhood sexual abuse has no sympathetic audience (familial, medical, or otherwise) to talk to about her sexual trauma or about her developing sexual curiosity. Consequently, as she grows up, her mental illness is not diagnosed or treated, and there is no safe space for her to explore her sexuality.

At the same time as underscoring this lack in Una's lonely journey through PTSD and from girlhood to womanhood, the graphic memoir also foregrounds the sexual precarity that comes with being labelled a mentally ill girl. Through this label, the autobiographical subject is invested with unreliability and becomes vulnerable to further sexual trauma (see Una 80-82, 87, 107-108). Becoming Unbecoming thus displays the dangers Una faced as she was growing up, illuminating the failure and/or inability of educational, medical, and familial institutions to create a safe and supportive environment in which the autobiographical subject would be able 
to recover from PTSD and to also safely explore her sexuality. Una's experiences of childhood and adolescent sexual violence and the trauma she carries with her remain unspeakable until her adulthood (Una 107, 205). The narrator relates how she was raped by Damian in 1975, when she was ten years old, and then by Terry a year later (Una 23-24, 35-36). At fourteen, as she further explains, she also suffered a gang rape initiated by her boyfriend, Theo (86-88). As she grew older, she did not refrain from seeking (sexual) intimacy and from wanting to explore her sexuality. However, because of her search for sexual self-expression, she was stigmatized, shamed, and further abused, and her mental health further deteriorating as a consequence.

Symptoms of PTSD, like repeated nightmares, first manifested when Una was ten years old and worsened as she was growing up because she never spoke about her abuse (92-102, 111). As the narrator explains, when she grew older, she tried to tell people about what had happened to her, but she did not find a responsive audience (105). "It's not easy to discuss any of this openly," she relates (107). "It makes other people uncomfortable, embarrassed and angry. Not the response you need if you are distressed or traumatized" she continues, further wondering how other people are "supposed to make sense of your emotional responses" if they do not know what causes them (107). Referring to the ostracism people with experience of sexual violence often feel, and her family's shame in her because of her inability "to be normal," Una explains that "being repeatedly assaulted, shamed and blamed for it, shook [her] to the core in a unique way that has not been great for [her] mental health" (107-108). As such, in addition to accounting for the impact of the actual assaults she suffered, Una also lucidly describes the psychological damage caused by the lack of support networks that, as discussed below, seems to be partly perpetuated by the social and cultural stigmatization of active (adolescent) female sexuality.

The epidemic of sexual violence against girls and women, which affected the autobiographical subject directly and indirectly, also significantly contributed to her mental 
illness. Una grew up in Yorkshire, UK, at a time when gendered crimes against women and girls reached a peak, with the media and the police blaming the "loose morals" of victims for them (64). In addition to her own private trauma, she thus had to cope with the ongoing slutshaming and victim-blaming that dominated news coverage of these crimes. "In order to survive" in a period notorious for "its vicious misogyny," she explains in the graphic memoir's "Afterword," "I internalized much of the unhelpful and contradictory nonsense that I heard, simply because I was a child" (202). References to the gendered crimes of Yorkshire appear intradiegetically; as the narrator recounts her story of growing up, she situates it in a broader socio-historical context, where these crimes prevail $(23,28,71)$.

In addition, newspaper clippings fracture her life narrative as they introduce information about the Ripper's crimes. An open letter to him as well as articles placing responsibility on victims by framing them as prostitutes and by giving advice to girls about how to protect themselves lead readers to understand Una's private story as part of a larger whole (see $29,48,54$ ). At the same time as these articles place responsibility on the victims through their prostitution accusations, via her narrative voice and visual illustrations, Una underscores the fact that these were ordinary women and girls. She thus counters the aforementioned official, public information. The fragmentariness of comics easily accommodates such complementary documentation, thus allowing the artist to structure Una's personal narrative of PTSD and sexual abuse as embedded within and impacted by the broader, collective narrative of the Ripper's crimes in Yorkshire during the 1970s. In one instance, Una's avatar holds an empty speech balloon and floats over a newspaper clipping that describes the police's inability to trace the Ripper, the policing of brothels as potentially leading the murderer to "prey on innocent women," and the dangerous lives of prostitutes, who know that violence can be part of their job (54). The depiction of young Una floating over the newspaper 
clipping, while holding onto her empty speech balloon can be read as pointing to how she processes and becomes affected by this information as a vulnerable child.

Her vulnerability, as well as the repetitive and injurious victim-blaming and slutshaming reproduced through the media and affecting the autobiographical subject, constitute examples of what Maria P. P. Root calls "insidious trauma" (241), which in Becoming Unbecoming prolongs Una's PTSD. According to Root, insidious trauma can stem from everyday situations of discrimination, like sexism, that can cause feelings of anxiety and distress in victims. "The frequency of insidious trauma," she writes, "results in a construction of reality in which certain dimensions of security are not very secure," thus forcing the victim to adapt to a new unsafe realm (241). Una does not seem to adapt to this reality as suggested by the increasing sense of ongoing threat, insecurity, shame, and guilt she feels (see 42,66 ) and her return to her original sexual traumas prolongs her mental illness. At the same time, she internalizes the social and cultural framing of any signs of active female sexuality as indicative of immorality and promiscuity. The repeated assertion that gendered crimes against women and girls are triggered by the perpetrator's desire to kill prostitutes and women of loose morals (48) increases her negative feelings and her precarity. She is unable to regain her mental health within this injurious context and her PTSD symptoms endure as she moves into adulthood. By accounting for the above, the graphic memoir alerts readers that Una's journey from girlhood to womanhood is marked by sexual violence, untreated PTSD, and the stigmatization of female sexuality, which is rendered invisible, more so, for mentally ill women and girls.

PTSD constitutes an outcome of sexual abuse for 30-94\% of survivors (Jina and Thomas 19). The Diagnostic and Statistical Manual of Mental Disorders (DSM-5) states that women and girls are more prone to PTSD because they are more frequently exposed to interpersonal, sexual violence. In Becoming Unbecoming, Una is repeatedly assaulted as a child and she grows up in an extremely precarious context in which she feels shame and remains 
silent about her sexual traumas. Due to the prolonged absence of sympathetic listeners, her PTSD remains undiagnosed and untreated. In addition to PTSD, childhood sexual violence can also cause risky sexual behaviour, eating disorders, substance abuse, and suicidal tendencies (Jina and Thomas 19). Jennie G. Noll et al. write that having suffered sexual abuse during childhood may also trigger sexual shame in survivors (11). As discussed above, Una presents most of these symptoms (see Una 92-101, 108-11). In addition, because she explores her sexuality and desires intimacy, she is targeted as a slut; she is shamed and stigmatized at school, and finds no support at home since her parents seem unable to help her, further marginalizing and punishing her for her behaviour (see $24,27,49) .{ }^{8}$ Thus, for Una, shame also stems from her ongoing stigmatization, which highlights the injurious role of the unsafe social context she had to navigate following her assaults. While PTSD and its impact on the autobiographical subject's development cannot be seen, the comics medium offers Una the possibility to effectively address and communicate them. Through the use of braiding and metaphor, Becoming Unbecoming unveils the realities concerning female sexuality and PTSD in the aftermath of childhood sexual abuse.

\section{Braiding}

In The System of Comics (2007), Thierry Groensteen introduces the term "braiding" to account for the repetition of particular images and image sequences in graphic narratives (146). Jan Baetens and Pascal Lefèvre also note that comics demand "“a reading capable of searching, beyond linear relations, to the aspects or fragments of panels susceptible to being networked

\footnotetext{
${ }^{8}$ The first incident of Una's shaming occurs because she implicitly exposes her interest in a boy at school occurs when she draws a painting of him and the teacher displays it on the wall. Once her fellow students realize who the boy in the painting is, they begin to laugh and make fun of her desire causing her feelings of embarrassment (27).
} 
with certain aspects or fragments of other panels"" (qtd. in Groensteen 146). For Groensteen, "braiding is precisely the operation that, from the point of creation, programs and carries out this sort of bridging" (146). As Silke Horstkotte and Nancy Pedri write, through braiding, components of comics become situated "in a potential, if not actual, relation with every other, leading to a densification of detail that charges the layout with meaning" (336). In Becoming Unbecoming, specific images recur throughout the narrative with some differentiations to foreground Una's suffering and to illustrate the impact of slut-shaming on her PTSD.

For instance, the narrative opens with an image of the autobiographical avatar in a white dress carrying a burdensome speech(less) balloon on her back as she tries to climb a black mountain. This motif reappears frequently throughout the book to illustrate the weight of her unspeakable secret and the psychological burden it causes for her. Unlike the book's cover, where Una is depicted in a red dress floating over a dark forest as she holds onto her empty speech balloon, on the first page of the narrative, the balloon gravitates downwards making her way ahead difficult. The red color of her dress on the cover alludes to Little Red Riding Hood, the emblematic fairy-tale character, who is said to metaphorically depict a naïve pre-adolescent victim of rape (see Brownmiller 343-344). In contrast, throughout the narrative, Una is mostly depicted in a white dress. Unlike the allusions triggered by the color red, white can be interpreted as symbolizing female purity and innocence on the one hand and madness on the other. ${ }^{9}$ Her dress, therefore, can be read as visually marking Una's positioning as trapped between stereotypical understandings of female madness, which she seems to embody in the

\footnotetext{
${ }^{9}$ The signification of white as a marker of female madness emerged through the late nineteenthcentury photographic representations of Jean Charcot's star hysteric patient, Augustine, in a white gown, themselves based on theatrical, filmic and painterly representations of William Shakespeare's Ophelia -- the artistic prototype of female madness (Showalter 86).
} 
narrative, and (sexual) purity and innocence, to which, according to the view of those around her, she fails to adhere. This causes her marginalization within school and family networks and contributes significantly to her PSTD.

In addition to her white dress, the topographic depiction of her PTSD as a dark mountain reappears with slight variation after we learn of Una's rape at the age of ten and following "an open message to the Ripper" in the Yorkshire Evening Post (Una 48). The message refers to the Ripper's "dreadful hate for prostitutes," which "went terribly wrong" when he attacked "an innocent 16-year-old lass, a happy, respectable working class girl from a descent Leeds family" (48). On the same page, Una is drawn trying to balance herself on a tightrope. On her right side, the sky and the mountains are representative of the carelessness that is associated with being perceived as a respectable, innocent girl. On her left side, the word "whore" in different languages fills the panel. The coming together of these contrasting representations subtly and effectively communicates Una's struggles to balance herself between innocence and respectability and the consequences of being labelled "slut."

Once her fellow students discover that, Una "borrowed someone else's" boyfriend because unable to find her own, they began viewing and labelling her as a slut (49). After noting that she "hadn't really understood the situation," Una does find a boyfriend of her own. However, she admits that: "He was older than me [and] he was repulsive, everyone thought so. It used to make me quite sick. Other kids laughed at me but I was happy, because I was longing to be loved" (49). The contrast between her perspective and that of others points to Una's risky (sexual) behavior resulting from childhood sexual trauma that, having remained untreated, has caused her further harm. Depictions of her walking forward carrying a burdensome speech(less) balloon are repeated after these incidents and follow her intradiegetic references to the unpunished gendered crimes of the Yorkshire Ripper. At this instance, however, instead of climbing a dark mountain, Una walks on a surface, underneath which the handwritten 
reproduction of the message to the Ripper in addition to other newspaper entries that blame female victims for crimes against them are reproduced. The texts and their position below Una highlight the dangerous social contexts through which she must navigate her PTSD by also noting the ineffectuality of the police in arresting the criminal. Following her assault and labelling, she is depicted walking over what verbally presents a contrast between the prostitutes the Ripper was said to hate and the innocent girl he attacked. This textual replacement of the dark mountain thus foregrounds Una's vulnerability as she must navigate through a dangerous environment, where gendered violence remains unpunished and female victims are discursively formed as prostitutes, and thus blamed for the harms they suffer.

Early on, Una explains that her favorite singer, Val Doonican, taught her through his song, "Walk Tall," "to walk straight and look the world right in the eye" (13). Even though she tried to do so, she later explains that she "learned to lower her gaze" (14, emphasis mine). Her comment points to the social construction of female submissiveness as displayed through women and girls' lowering of their gaze. ${ }^{10}$ The visual embodiment of Una accompanying this caption is also repeated with some alterations throughout the narrative. At this instance, the autobiographical avatar is lying on a surface in her white dress, in a sleeping or dead-like posture that reflects a passivity similar to the one suggested by the female aversion of the gaze. Her head, arms, and feet seem shackled to the ground. The dark weights pulling her downwards and preventing her from rising become deeply ingrained underneath the surface. Furthermore, their roots branch out, strongly suggesting the depth of Una's suffering -- that is otherwise invisible on her body -- and foreshadowing the violence she is about to be exposed to. This image is reproduced when the narrator relates that her mother took her to the doctor for

\footnotetext{
${ }^{10}$ On the significance of female spectacles' aversion of their gaze from their spectators as a sign of female submissiveness, see Dyer 194; Henley 163.
} 
contraceptive medication during her adolescence, after she had discovered that Una had a "repulsive" boyfriend (49-50). "An unfortunate side effect of the contraceptive pill," she explains, "was that, when they found out I took it, boys felt even more entitled to my body" (50). As she mentions that her search for love was unsuccessful and her slut shaming continued, the repetition (with a difference) of her aforementioned sleeping or dead-like figure reappears (50).

In this case, the deeply rooted darkness of the previous depiction is replaced by a long text describing the rules governing the performance of adolescent girls' sexuality (50). Una is lying over words that unveil the social double standards of sexual gender roles as well as the pressures and absurdity that accompany the display of active female sexuality during adolescence. As she lies in her passive posture, she seems defeated by unrealistic expectations that require girls to deny any sexual desire, while satisfying the needs of their male sexual partners. Indeed, at the beginning of this narrative fragment, the narrator explains that "the rule was that girls were supposed to keep boys under control [but she] didn't seem able to do this" (50). The replacement of the visual image with verbal text, then, further specifies the autobiographical subject's struggles by offering details about her inability to cope with absurd social standards regarding adolescent female purity and the absence of sexual desire (50).

Una's sleeping or dead-like image appears once again when she describes her identification as a mentally ill person at school after her ongoing slut-shaming and the unreported assaults she had suffered (fig.1). At the age of fourteen, she was removed from school and sent to a psychiatrist as something unidentifiable troubled her (81). At this instance, once again, Una is visually depicted lying on a surface in a sleeping or dead-like posture. Una's sleeping or dead-like representation visually embodies her inability to escape from sexual trauma. The dark weights that initially pull and anchor her to the ground and become deeply rooted therein, which then transform into the textual representation of the suffocating social 
expectations concerning the sexual behaviour of girls, ultimately turn into a vast darkness into which she seems to be sinking. The surface on which she is lying dominates the page and her figure almost blends into darkness, illustrating her inability to detach herself from it.
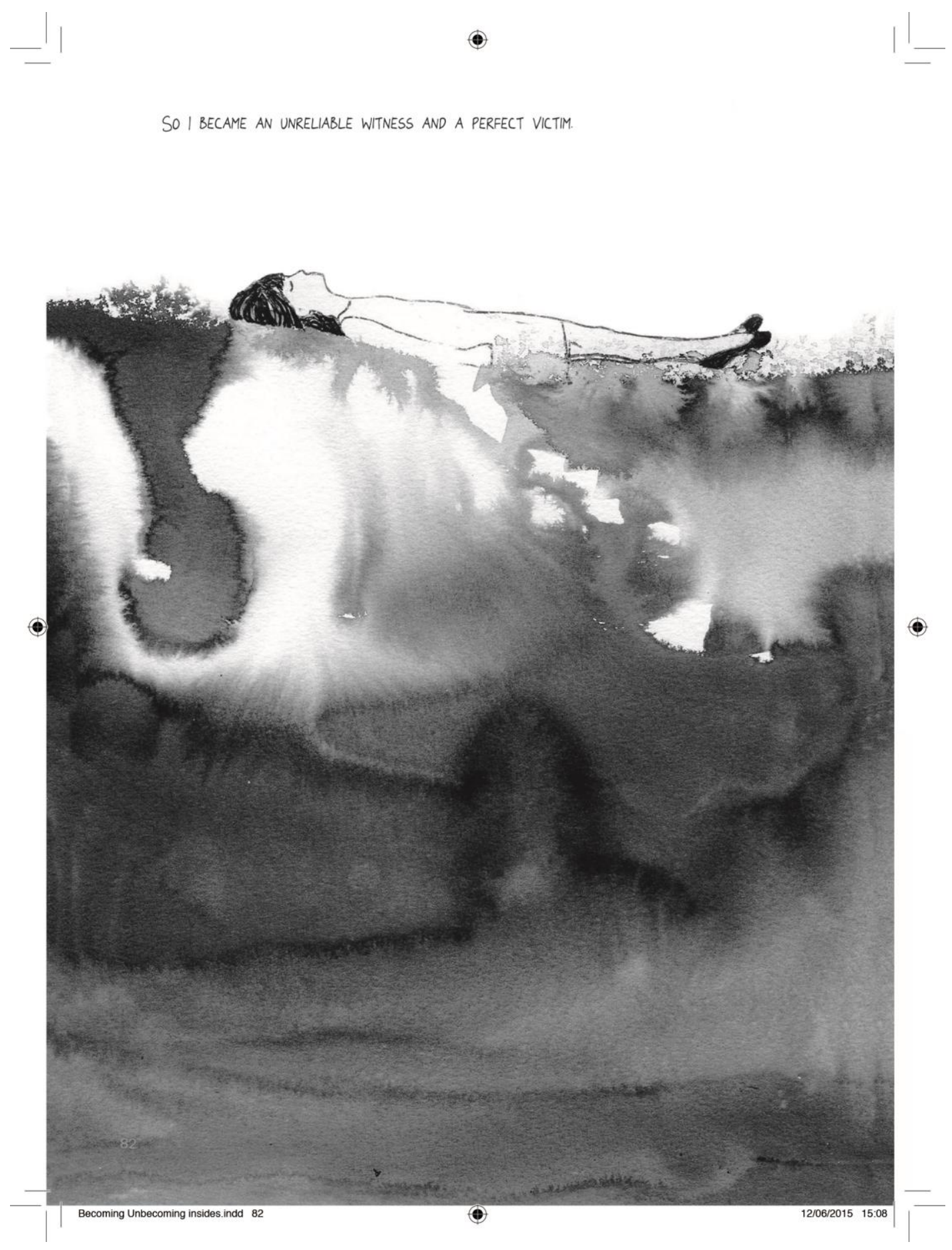

Figure 1: page 82

Images reproduced with permission from Becoming Unbecoming by Una (Myriad Editions, 2015) (C) Una, 2015, www.myriadeditions.com 
After being labelled mentally ill, Una explains that she "became an unreliable witness and a perfect victim" (82). ${ }^{11}$ The full implication of this new status is reinforced when, following this statement, she suffers a gang rape (85-89). The repetition of Una's image and the changing surfaces on which she lies foreground the implicit, injurious impact of the stigmatization of female sexuality on her PTSD and on her developing sexuality. The third and final repetition of this image also foreshadows the trauma that is about to emerge from her gang rape that is narrated in subsequent pages. In Becoming Unbecoming, then, braiding stresses Una's precarity following her interpellation as a slut and a mentally ill female person while also underscoring her solitude in her difficult journey through PTSD. The space through which she navigates, in the form of mountains and other surfaces, is manipulated by Una to facilitate the visualization of her autobiographical avatar's suffering. Her use of nuanced metaphors also serves the lucid representation of Una's mental illness and developing sexuality in the aftermath of abuse.

\section{Metaphors}

Elisabeth El Refaie writes that the most common metaphors used to describe depression in graphic illness narratives have to do with "darkness, descent, or being trapped in a tight place," while "the process of recovery is framed in terms of a battle or journey" (150). Sad feelings, she continues, "tend to express themselves in a slumped body posture," and metaphors of “depression as a burden are widespread" (150). El Refaie's analysis of metaphors in the graphic

\footnotetext{
${ }^{11}$ Janine Benedet and Isabel Grant note that a mentally ill woman's testimony of sexual assault may be questioned because "she must confront a criminal trial process that was not designed in contemplation of her as a witness" (515). The "tendency to infantilize women with mental disabilities, thereby diminishing their credibility and depicting them as hypersexual when they engage in any sexual activity" also worsens the situation for them (515).
} 
depiction of depression can illuminate the ways in which Una uses them to depict PTSD caused by sexual abuse. Becoming Unbecoming is replete with images of darkness, through which Una must navigate (see Una 93-101). Her depictions of moving ahead with the burden of her empty speech balloon and the dark mountains she must overcome are also very similar to the metaphors El Refaie identifies in her analysis of Darryl Cunningham's Psychiatric Tales and Brick's Depresso. However, in Becoming Unbecoming, these metaphors express Una's gendered experience of PTSD caused by childhood and adolescent sexual abuse, which becomes prolonged within the precarious context she must survive in without psychological support.

Pedri and Staveley also write of the increased use of "game and game-play" metaphors in graphic illness narratives, noting that such "ironic visual metaphors $[\ldots]$ communicate the complexity, exhaustion, and oftentimes despair of a medicalized human existence as well as the embodied experience of self-disintegration caused by illness" (232). Their analysis of how such game-play metaphors mediate experiences of illness can help better understand their relation to the representation of sexual trauma and mental illness in Becoming Unbecoming. Una uses such metaphors to mediate the autobiographical subject's reduction to invisibility during and after her sexual assault and to connect her suffering to that of other women and girls as further explained below. That these metaphors allude to children's playing processes as they simultaneously mediate the autobiographical subject's dehumanization during her rape points to the affective impact such metaphors can have in a sexual trauma narrative. As the adult, distant narrator describes her abusers, the autobiographical avatar is drawn with a friend during a den-making game. Terry, the man who raped Una when she was approximately eleven years old, is then depicted smiling as he invites her to join him behind some bushes. No additional information relating to the rape appears at this point and readers are called to make inferences about what transpired. 
It is only in a footnote at the end of the book that Una explains that for years she did not use "the word "rape"" to describe what had happened to her, even though this is what it was (205). This explanation highlights the silencing effect shame has on victims of sexual abuse. Indeed, Maria Elena Vidal and Jenny Petrak note that shame can result from traumatic stress caused in women after adult sexual assault (159-171). Bernice Andrews et al. also stress the role of shame "as a mediator between childhood abuse and adult psychopathology" (67). In Becoming Unbecoming, Una's silence as she navigates through her PTSD evokes her own shame, which worsens due to her parents' shame in her and her ostracism (see 52, 107). The narrator further explains that "for a long time, even hearing the word rape would shock and numb [her]... leaving [her] distressed for so long that she'd miss conversations" (112). As such, she also points to the power of the mere utterance of the word to cause psychosomatic reactions in her by triggering her original wound.

Following her implicit and silent allusion to her rape by Terry, which also displays the silencing impact of shame, Una's avatar disappears and the clothes she was wearing during the assault are drawn as paper-doll parts. By rendering the avatar invisible and reduced to paperdoll clothing parts that young girls play with, the graphic memoir shows how Una's subjectivity disintegrates through her sexual assault. However, textual elements on the same page render adult Una's voice audible and visible, demonstrating her survival beyond abuse and PTSD. Initially, a caption defines the word "jeans" (36) and a speech balloon relates that "it was the seventies so [her jeans] would have been flared" (36). The cartoonist foregrounds the centrality of jeans in how she remembers her assault by incorporating extended textual information about the quality of her jeans and presenting her assumption about their style. At the same time, she points to the constructedness of her memories as those are recreated in Becoming 
Unbecoming. ${ }^{12}$ While her avatar is absent from this visual arrangement, a speech balloon with typewritten font relates that her abuser told Una to wear a skirt in order to make things easier next time, and another one mediating the adult survivor's voice confirms that these were indeed his words as if to eliminate the potential disbelief of readers (36). The multi-layered narrative structure of comics allows the simultaneous display of the erasure of the young autobiographical avatar's subjectivity during her assault through the metaphor of paper-doll clothing parts and of the adult narrator's move beyond that as indicated by her textual presence.

The game-play metaphor of paper dolls first appears before Una's accounts of abuse and trauma, when she mentions her favorite singer (13). Precisely because this is a representation of Una prior to her abuses and PTSD, she is depicted without her white dress; she is wearing a pair of trousers and a sweater as she plays her guitar. Rectangular paper tabs, which reappear in the depiction of Una's clothes as paper-doll parts after her rape, surround her figure in this case. Suggesting that this bodily depiction had been previously assembled into a unified whole, they allude to the cartoonist's authorial presence. Simultaneously, they preserve a childish game dimension in Una's representation, which contrasts with the difficult contents of the graphic memoir. ${ }^{13}$ This metaphor also occurs when the narrative refers to the violent gendered crimes of the Yorkshire Ripper. In this instance, paper-doll body parts and clothes are scattered on the page (33). Since facial attributes are missing, the remaining paperdoll parts evoke the reduction of women and girls to mere bodies that can be easily torn to

${ }^{12}$ For a discussion on memory as an active, contextualized re-interpretation of the past see King 1; Huhn 147-169.

${ }^{13}$ I also read Una's simplistic cartoony depictions of the autobiographical avatar as a means to foregrounds her childishness, which stands in contradiction with the painful story that is narrated. 
pieces (both literally and metaphorically) through sexual violence and invest these female body parts with interchangeability. Varying ways of assembling paper-doll parts allow different bodily formations to transpire and, as such, this game-play metaphor points to how Una as well as other women and girls become deprived of their individuality and subjectivity through the violence they suffer.

Catherine Appleton and Kerry Mallan note that Una's first image (see Una 13) "in the manner of a cut-out doll [functions] as a generic image of female youth that suggests she could be any girl," further pointing out that her simplistic visual embodiment makes of her one among many $(50,58)$. Her assaults and through her mental illness erase Una's individuality. Like the other female presences captured via paper-doll parts, she too becomes anonymous, disposable, ephemeral, and less-than-human. Their vacant presence on the page, however, is undone at the end of Becoming Unbecoming, which closes with the cartoonist's realist depiction of her adult avatar and her homage to the twelve women murdered by the Ripper through full-page visual depictions that foreground each one's individuality. In this way, the graphic memoir renders these women visible, restoring their identities and removing the anonymity that had veiled them during their assaults. The paper-doll game-play metaphor foregrounds the invisibility thrust upon sexually abused and mentally ill women and girls but, through the interchangeability implied by the game, it also connects Una's personal story with those of the abused and murdered women and girls of Yorkshire. Therefore, disintegration, in this case, emerges out of gendered sexual crimes that can lead to trauma and mental illness and not by the illness itself.

The shattering impact of mental illness on the autobiographical subject manifests through the visual depiction of her collapse into pieces after the description of her rape by Terry and the narrator's account of PTSD symptoms such as the constant fear that something was after her $(35,38)$. In the visual register, Una's avatar is unable to sleep at night; she lies in bed with a pair of scissors at her side to defend herself if needed and leaves her bedroom door open 
(38; see also 42). On the same page, the narrator explains that she always feels the "uneasiness of turning into a new creature" (38). The subsequent page is wordless. Una's facial attributes and body parts, together with her red dress, are drawn scattered across the page, disconnected from each other, visually displaying her shattered subjectivity in the aftermath of her trauma. The red color of her dress recalls her depiction on the book cover and its associations with Little Red Riding Hood. Because of its allusions to blood, red can be understood as pointing towards her transition from girlhood to womanhood through menstruation at the same time as indicating her suffering. Hence, when read in relation to the narrator's comment about her "uneasiness of turning into a new creature," the metaphorical depiction of Una in pieces marks the impact of PTSD on her embodied transition from girlhood to womanhood.

Indeed, on the two following pages, the narrator explains that her "body was changing," but that her "wings didn't seem to work very well" (40-41). In the visual register, Una appears as an insect with a human head, initially without and later with wings attached to its back (fig. 2). The autobiographical avatar is also frequently drawn with a human body wearing her white dress and with wings attached to her back (see 76,78). These malfunctioning wings visually mark her difference from the rest of the characters due to the impact of sexual trauma and PTSD on her developing femininity. While Becoming Unbecoming suggests that Una's experiences of sexual violence are part of the normal cultural make up in Yorkshire during the 1970s, she becomes stigmatized and isolated because of what is perceived by those around her as "abnormal" behavior. Una explains that "traumatised children can develop behaviour that the adults around them perceive as delinquent, so there's punishment and further marginalization" (45). In addition, she refers to the difficulties others demonstrate when it comes to understanding the behavior of traumatized people, and mentions her "effort of trying (and failing) to be normal in some elusive way, [which together with] her family's obvious shame in" her caused her frustration and anger (107). Her difference, as indicated by her hybrid 
half-human/half-insect visual embodiments, manifests within unsafe and unsupportive environments in which she does not receive a diagnosis or cure for mental illness and is unable to safely explore her sexuality.
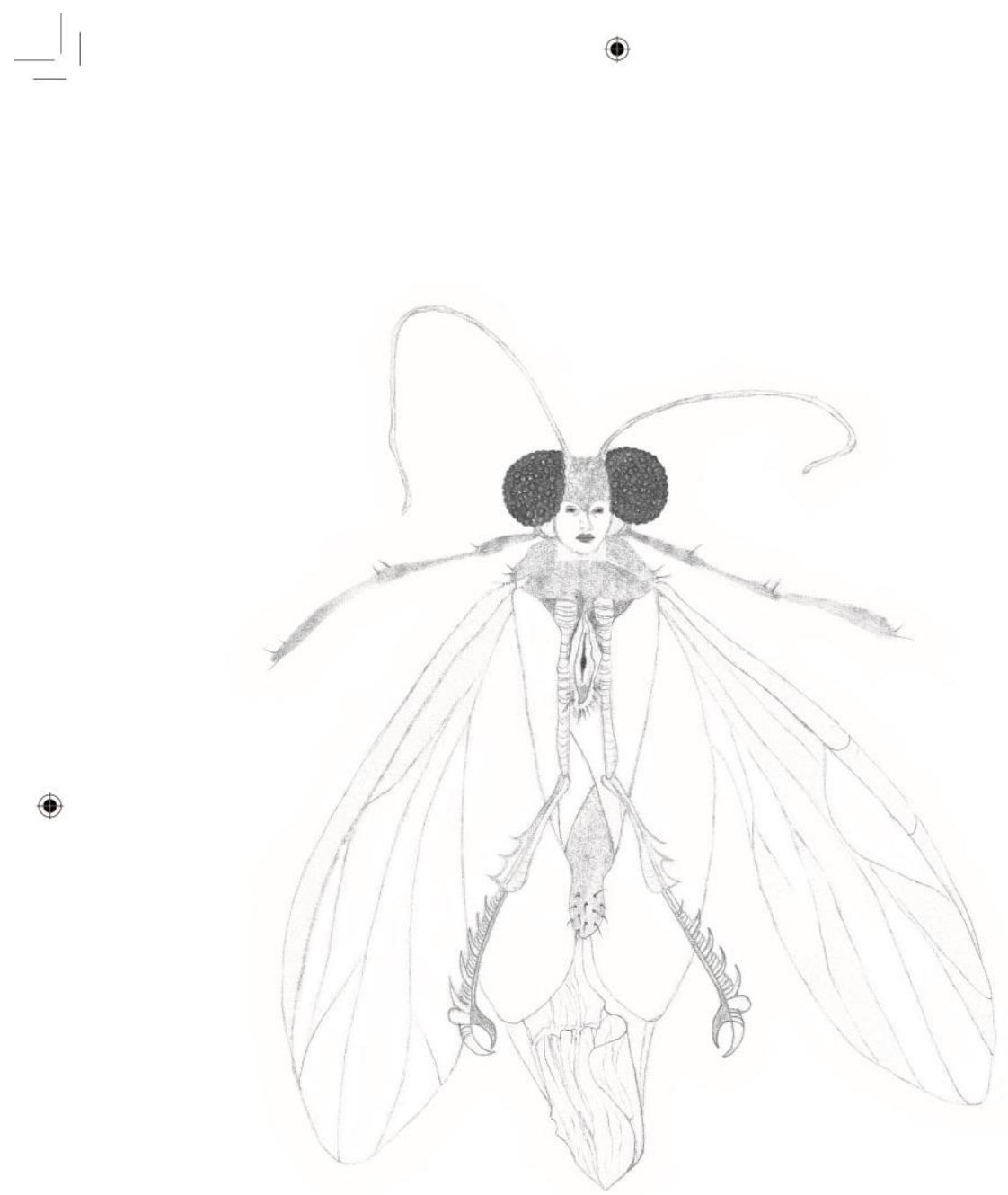

MY WINGS DIDN'T SEEM TO WORK VERY WELL PERHAPS THEY WERE JUST DECORATIVE?
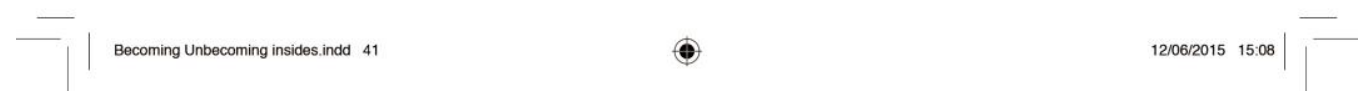

Figure 2: page 41

Images reproduced with permission from Becoming Unbecoming by Una (Myriad Editions, 2015) (C) Una, 2015, www.myriadeditions.com 
Appleton and Mallan note that in Una's full-page depictions as an insect with a human head, "the most prominent feature of her changed body is the vagina placed over her heart, expressing confusion between sex and love" (54). While the narrator does account for her unsuccessful adolescent search for love and her (abusive) sexual encounters, the centrality of the vagina over her heart also underscores her embodied femininity as a central factor that led to her transformation into a new "creature" through sexual abuse and PTSD. Una's visual embodiment as a half-human/half-insect creature metaphorically represents her deviation from the norm in her journey from girlhood to womanhood, which was also pointed out by a boyfriend she had in her early twenties (42). As Courtney Donovan and Ebru Ustundag argue, her "repeated visual depictions of personal metamorphosis capture invisibilized traumatic experiences that leave a lasting effect that may be difficult to articulate in words" (231). Una's half-human/half-insect depictions and the narrator's use of the term "creature" to describe her embodied self during adolescence allude to Mary Shelley's monster in Frankenstein (1999) and to Gregor Samsa's metamorphosis into an insect in Franz Kafka's novella (2015). Like Kafka's Gregor and Shelley's monster, the autobiographical avatar's status as a marginalized outsider within her family and the broader social context is visually mediated through her creaturely embodiment. Unlike her fictional ancestors, which have become the literary emblems of “otherness," Una's creaturely self is marked by her mental illness, her femininity, and her developing sexuality. Her half-human/half-insect hybridity visually captures her bodily transformation into a woman and her gendered experience of sexual abuse and PTSD.

A further metaphorical representation that illustrates Una's conflation with elements from the natural environment and that facilitates the visual expression of her "non-normative" development exists at the very start of Becoming Unbecoming. In this instance, Una is drawn seated, with her body turned towards readers in a position that intradiegetically marks her role as the narrator of the story that is to unfold (Una 16). Rather than depicting the autobiographical 
avatar looking at readers, the cartoonist drew a tree emanating from her genital area. The tree's trunk is positioned in front of her torso and its brunches and twigs replace her head. If we perceive the face as a marker of one's individuality and identity, then its removal from Una's visual embodiment and its replacement by the upper part of a tree once again undoes her status as an unmarked human being. In addition, her defamiliarizing depiction unsettles the affective connection or identification that could have been created through the direct return of her gaze to readers. Like the existence of what looks like a vaginal opening on Una's creaturely depictions, the emergence of the tree particularly from her genital area, which leads to the creation of a new hybrid creature, can be understood as visually displaying the centrality of her sexuality and her sexual suffering on her psychosexual development. After the narrator describes her first rape, a full-page depiction of another tree with some of its branches unevenly growing outwards on its right side also mirrors Una's development (47). In its conflation of the human with the natural, then, Becoming Unbecoming mediates Una's experiences and the mark of sexual violence and PTSD on her journey from girlhood to womanhood.

\section{Conclusion}

In its complex display of PTSD following childhood and adolescent sexual trauma, Becoming Unbecoming underscores the need to address issues around abused and mentally-ill women and girls' sexuality in medical care to prevent further harm from occurring. In addition, it enhances readers' understanding of female experiences of childhood and adolescent sexual violence and mental illness. Una's manipulation of the comics form has allowed her to effectively mediate her autobiographical subject's suffering, her survival beyond sexual trauma, and her transition from being a girl into being a woman. Braiding, game-play, creaturely and other hybrid metaphors captured through Una's visual embodiments, the medium's visual/verbal combinations, and alternations in narrative voice lucidly illustrate the 
impact of sexual violence and PTSD on the protagonist's psychosexual development. Becoming Unbecoming is therefore an important educational tool and an example of feminist activist art because in telling Una's story it succeeds in removing responsibility, stigma, and shame from female abuse survivors, and in highlighting the harms that can emerge from the lack of appropriate support networks for abused and mentally ill women and girls. It successfully does so because the comics form enables thought-provoking and imaginativelynuanced displays of issues concerning female sexuality and mental illness that can trigger readers' imagination, allowing affective and ethically charged engagements with sensitive issues of this kind.

Acknowledgements:

I would like to thank the editors of the special issue, Nancy Pedri and Irene Velentzas, for their insightful comments on my essay.

Disclosure Statement:

No potential conflict of interest 
Works cited

Andrews, Bernice et al. "Predicting PTSD symptoms in victims of violent crime: The Role of Shame, Anger, and Childhood Abuse.” Journal of Abnormal Psychology, vol. 109, no. 1, 2000, pp. 69-73.

APA. Diagnostic and Statistical Manual of Mental Disorders, Fifth Edition. American Psychiatric Association, 2013.

Appleton, Catherine and Kerry Mallan. "Filling the Silence: Giving Voice to Gender Violence in Una's Graphic Novel Becoming, Unbecoming." International Research in Children's Literature, vol. 11, no.1, 2018, pp. 47-64.

Barry, Lynda. One! Hundred! Demons!. Sasquatch Books, 2002.

Bechdel, Alison. Fun Home: A Family Tragicomic. Jonathan Cape, 2006.

Benedet, Janine and Isabel Grant. "Hearing the Sexual Assault Complaints of Women with Mental Disabilities: Evidentiary and Procedural Issues.” McGill Law Journal, vol. 52, no. 3, 2007, pp. 515-552.

Brownmiller, Susan. Against Our Will: Men, Women, and Rape. Bantam, 1976.

Buckley, F. Peter et al. "Sexual Behaviour in Persons with Serious Mental Illness: Patterns and Correlations." Sexuality and Serious Mental Illness, edited by Peter F. Buckley, Overseas Publishers Association, 1999, pp. 1-20.

Chute, L. Hillary. Graphic Women: Life Narrative \& Contemporary Comics. Columbia UP, 2010.

Cunningham, Darryl. Psychiatric Tales: Eleven Graphic Stories about Mental Illness. Blank Slate, 2010.

Dalmaso, Renata Lucena. “The Visual Metaphor of Disability in Sarah Leavitt's Graphic Memoir Tangles: A Story about Alzheimer's, My Mother and Me." Ilha do Desterro vol. 68 , no. 2, 2015, pp. 75-92. 
Davison, Joanna and Annette Huntington. "Out of Sight: Sexuality and Women with Enduring Mental Illness.” International Journal of Mental Health Nursing, vol. 19, no. 4, 2010, pp. 240-249.

Deegan, E. Patricia. "Human Sexuality and Mental Illness: Consumer Viewpoints and Recovery Principles.” Sexuality and Serious Mental Illness, edited by Peter F. Buckley, Overseas Publishers Association, 1999, pp. 21-34.

Donovan, Courtney and Ebru Ustundag. "Graphic Narratives, Trauma and Social Justice." Visual Research and Social Justice, vol. 11, no. 2, 2017, pp. 221-237.

Doucet, Julie. Dirty Plotte. Drawn and Quarterly, 2003.

Drechsler, Debbie. Daddy's Girl. Fantagraphics, 2008.

Dyer, Richard. Only Entertainment. Routledge, 1992.

El Refaie, Elisabeth. "Looking on the Dark and Bright Side: Creative Metaphors of Depression in Two Graphic Memoirs.” a/b: Auto/Biography Studies, vol. 29, no. 1, 2014, pp. 149174.

Forney, Ellen. Marbles: Mania, Depression, Michelangelo and Me. Penguin, 2012.

Foucault, Michel. Discipline and Punish: The Birth of the Prison. Translated by Alan Sheridan. Vintage Books, 1995.

---. Madness and Civilization: A History of Insanity in the Age of Reason. Translated by Richard Howard. Vintage Books, 1988.

---. The Will to Knowledge. Vol. 1 of The History of Sexuality. Translated by Robert Hurley. Penguin, 1998.

Gloeckner, Phoebe. A Child's Life and Other Stories. Frog books, 2000.

---. The Diary of a Teenage Girl: An Account in Words and Pictures. Frog Books, 2002. 
Green, J. Michael and Kimberly Myers. "Graphic Medicine: Use of Comics in Medical Education and Patient Care.” British Medical Journal, vol. 340, no. 863, 2010, pp. 574577.

Groensteen, Thierry. The System of Comics. Translated by Bart Beaty and Nick Nguyen, UP of Mississippi, 2007.

Henley, M. Nancy. Body Politics: Power, Sex and Nonverbal Communication. Prentice-Hall, 1977.

Horstkotte, Silke and Nancy Pedri. "Focalization in Graphic Narrative." Narrative, vol. 19, no. 3, 2012, pp. 330-357.

Huhn, Annette. Family Secrets: Acts of Memory and Imagination. Verso, 2002.

Jina, Ruxana and Leena S. Thomas. "Health Consequences of Sexual Violence Against Women.” Best Practice and Research Clinical Obstetrics and Gynaecology, vol. 27, no. 1, 2013, pp. 15-26.

Kafka, Franz. Metamorphosis and Other Stories. Penguin, 2015.

Kasthuri, Ravi Raghavi and Sathyaraj Venkatesan. "Picturing Illness: History, Poetics and Graphic Medicine.” Research \& Humanities in Medical Education vol. 2, 2015, pp. 1117.

King, Nicola. Memory, Narrative, Identity: Remembering the Self. Edinburgh UP, 2000.

Kominsky-Crumb, Aline. Love that Bunch, edited by Garry Groth, Fantagraphics, 1990.

Mathews, J. Graham. "Illness Narratives and the Consolation of Autofiction." Autofiction in English, edited by Hywel Dix, Palgrave Macmillan, 2018, pp. 125-143.

Michael, Olga. "Lolita Is Set Free: Questioning and Re-Inventing Constructions of Adolescent and Pre-Adolescent Female Beauty in Phoebe Gloeckner's Graphic Memoirs.” Female Beauty in Art: History, Feminism, Women Artists, edited by Maria Ioannou and Maria Kyriakidou, Cambridge Scholars, 2014, pp. 38-66. 
Noll, G. Jennie et al. "A Prospective Investigation of the Impact of Childhood Sexual Abuse on the Development of Sexuality." Journal of Consulting and Clinical Psychology, vol. 71, no. 3, 2003, pp. 575-586.

Pedri, Nancy and Helene Staveley. "Not Playing Around: Games in Graphic Illness Narratives." Literature and Medicine, vol. 36, no. 1, pp. 230-256.

Root, P. P. Maria. "Reconstructing the Impact of Trauma on Personality." Personality and Psychopathology: Feminist Reappraisals, edited by Laura S. Brown and Mary Ballou, Guilford P, 1992, pp. 229-267.

Sabin, Roger. Comics, Comix and Graphic Novels. Phaidon, 1996.

Shelley, Mary. Frankenstein, Or the Modern Prometheus. Wordsworth Classics, 1999.

Showalter, Elaine. 1986. "Representing Ophelia: Women, Madness, and the Responsibilities of Feminist Criticism." Shakespeare and the Question of Theory, edited by Patricia Parker and Geoffrey H. Hartman, Methuen, 1986, pp. 77-94.

Una. Becoming, Unbecoming. Myriad Editions, 2015.

Vidal, Elena Maria and Jenny Petrak. "Shame and Adult Sexual Assault: A Study with a Group of Female Survivors Recruited from an East London Population." Sexual and Relationship Therapy, vol. 22, no. 2, 2007, pp. 159-171.

Williams, Ian. "Comics and the Iconography of Illness," Graphic Medicine Manifesto, edited by MaryKay Czerweic et al., Penn State UP, 2015, pp. 115-142.

---. “Graphic Medicine: Comics as Medical Narrative." Medical Humanities, vol. 38, no. 1, 2012.

---. "Graphic Medicine: The Portrayal of Illness in Underground and Autobiographical Comics," Medicine, Health and the Arts: Approaches to Medical Humanities, edited by Victoria Bates, Alan Bleakley and Sam Goodman, Routledge, 2013, pp. 64-84. 